\title{
Evaluating the progress and needs of taxonomy since the Convention on Biological Diversity: going beyond the rate of species description
}

\author{
Elise Tancoigne $^{\mathrm{A}, \mathrm{B}, \mathrm{D}}$ and Guillaume Ollivier ${ }^{\mathrm{C}}$ \\ A Institut de Systématique, Evolution, Biodiversité, ISYEB - UMR 7205 CNRS MNHN UPMC EPHE, \\ Muséum National d'Histoire Naturelle, 25 Rue Cuvier, F-75005 Paris, France. \\ BINRA, UMR Lisis, IFRIS, Université Marne-la-Vallée, Cité Descartes, Champs-sur-Marne, \\ 5 Boulevard Descartes, F-77454 Marne-la-Vallée Cedex 02, France. \\ CINRA, UR0767 Ecodéveloppement, PACA Research Centre, Site Agroparc, CS40509, \\ F-84914 Avignon Cedex 9, France. \\ ${ }^{D}$ Corresponding author. Present address: University of Geneva, Boulevard Carl Vogt 66, \\ CH-1205 Geneva, Switzerland. Email: elise.tancoigne@unige.ch
}

\begin{abstract}
There is a long tradition of assessing the activity and progress of taxonomy with quantitative indicators, such as, for example, number of taxonomists, species described and species collected. These evaluations play a key role in the context of a worldwide concern over biodiversity and its governance. We have described and analysed these evaluations since 1992, the year in which the Convention on Biological Diversity (CBD) was adopted. We showed that despite the establishment of a dedicated body inside the CBD (the Global Taxonomy Initiative), these quantitative evaluations are mostly sporadic and independent initiatives, performed by non-taxonomists. They do not map the places where most of the taxonomic activities take place, and they are performed on small scales, with scarce and heterogeneous sources of data, making comparisons almost impossible. Most of the indicators they use refer to the activity of species description. We argue that there is a need to rethink the way we evaluate taxonomy today and we discuss why it is urgent to move beyond indicators of species description. We suggest the use of a new set of indicators that would focus on taxonomic resources and dynamics, instead of taxonomic outputs.
\end{abstract}

Additional keywords: capacity assessment, collections, Global Taxonomy Initiative (GTI), taxonomic impediment, text analysis.

\section{Introduction}

\section{A long tradition of quantitative evaluations of taxonomy}

Evaluating the progress and status of taxonomy through various metrics is not new. In 1939, the entomologist Brues measured, for the first time, the number of described species recorded in the Zoological Record (Brues 1939). In 1959, Blackwelder produced an inventory of taxonomists all over the globe, asking 'Are all [...] groups well known? Is the work finished on any of them? Is taxonomy still needed?' (Blackwelder 1959, p. 71). A few countries started to assess their taxonomic activity and resources in the 1960s (Spain, Balcells 1963; Australia, Ride and McCusker 1978; Britain, Advisory Board for the Research Councils 1979; the USA, Edwards et al. 1985), with some of them undergoing frequent assessments (Australia, United Kingdom). Today, both classical taxonomic indicators (e.g. number of described species, number of collected specimens, number of taxonomists) and classical scientometric indicators (e.g. number of publications, number of authors, number of journals) are regularly used to assess the progress and needs of the field. For instance, Joppa and his colleagues (Joppa et al. 2011) studied the rates of species description for six groups of taxonomists (i.e. those working on flowering plants, marine snails of the genus Conus, spiders, amphibians, birds and mammals), and Michán Aguirre et al. (Michán Aguirre and Llorente Bousquets 2003, 2010, Michán Aguirre et al. 2004, 2008) wrote a history of taxonomy in Mexico on the basis of its publications.

In the present article, we reflect on this practice of quantification of taxonomy. Enumeration is indeed never straightforward, nor devoid of preconceptions of the thing it measures. If you use IQ to measure intelligence, you endorse a specific vision of intelligence; if you use the number of described species to measure the activity of taxonomy, you endorse a specific vision of taxonomy. So, we wanted to know, how taxonomy is evaluated today? Is it evaluated with the right 
indicators? Do authors have the appropriate sources to perform their evaluations? Do the evaluations correctly map the places and taxa where taxonomic activity takes place?

\section{Why is this important?}

These questions are not solely the reflection of their authors' worries and desires for faithful reports in taxonomic matters. In 2014, a high number of exasperated taxonomists reacted collectively to a study published in Science that 'proposed practical actions to improve taxonomic productivity' (Costello et al. 2013, p. 413). Taxonomists protested, stating that 'we refute [their] end-user view that taxonomy is on the rise simply because more new species are being described compared with earlier decades, and that, by implication, taxonomic practice is a formality whose pace can be streamlined without considerable resources, intellectual or otherwise' (de Carvalho et al. 2014, p. 322). 'Far beyond discovering and naming new species, taxonomy is driven by evolutionary hypotheses that generate predictive classifications and improve our understanding of biotic diversity through meticulous systematic revisions and homology assessments' (de Carvalho et al. 2014, p. 323). Propositions to 'streamline' taxonomy have taken numerous forms. For instance, Janzen (1993) suggested to subcontract tasks (such as collection and sorting) to parataxonomists, who, by definition, have no scientific training in taxonomy. La Salle et al. (2009) promoted automatic descriptors extraction. Other authors have promoted the automatic identification of known species by pattern recognition (Weeks and Gaston 1997) and DNA barcoding (Hebert and Gregory 2005). Suggestions to delegate some taxonomic tasks (collecting, sorting, identifying) to unqualified technicians or machines bring a model of 'division of labour' to taxonomy. Asking whether taxonomy is accurately evaluated therefore matters. It is part of a trend that resists the application of the 'division of labour' model to taxonomy.

However, this question is not solely a question of disciplinary concern. In 1998, the Convention on Biological Diversity (CBD) Conference of the Parties endorsed a newly created body, the Global Taxonomy Initiative (GTI), with the following operational objectives: 'assess taxonomic needs and capacities from global to local levels and [...] generate information for decision-making in conservation and sustainable use of biodiversity' (GTI website, see https://www. cbd.int/gti/pow.shtml, accessed 12 October 2017). Twenty years later, evaluations of taxonomy play a key role on the stage of international biodiversity governance, instructing the CBD decisions, its conservation measures and efforts. In this context, questioning how those evaluations are made goes beyond curiosity or disciplinary concerns; it becomes political. So, the aim of the present paper is to answer the following questions: (1) who performs these studies on taxonomy; (2) where do these assessments of taxonomy take place; (3) where do these data on taxonomy come from; and (4) what are the indicators used to assess the progresses and activities of taxonomy?

\section{Materials and methods}

We performed a content and context analysis of these quantitative evaluations of taxonomy around the world.
We focused on a 20-year period (1992-2012), marked by the entry of taxonomy into the international political arena (CBD). We used several approaches to retrieve documents and information (queries on the web, queries on bibliographic and taxonomic databases and websites, calls to taxonomists). Our search process is presented in Appendix 1. We identified 84 documents that evaluate at least one aspect of taxonomy (e.g. number of taxonomists, number of collections, number of described species). We succeeded in retrieving $80 \%$ of them $(n=67)$. The list of documents, considered close to exhaustive, is presented in the Supplementary material. We described each document in terms of authorship, content and context of publication, e.g. year of publication, discipline of the authors or geographic coverage of the study. Appendix 2 presents the coding process as well as details of these descriptive variables. Robustness of the data comes from the iterative and collaborative properties of the process of coding (Saldaña 2012). We conducted a simple descriptive analysis for each of our variables (for percentages, we used $n=123$ authors and $n=67$ documents).

\section{Results: assessing the assessments}

This section addresses the four aims of the present paper, including the following: who performs these studies on taxonomy; where do these assessments of taxonomy take place; where do these data on taxonomy come from; and what are the indicators used to assess the progresses and activities of taxonomy? We show that these evaluations are mostly sporadic and independent, exogenous to the GTI. National dynamics better explain the origin of these evaluations. Their data come from limited and geographically imbalanced sources, and they mostly assess taxonomy through the rate of species descriptions.

\section{Mostly sporadic and independent evaluations, exogenous to the GTI}

Surprisingly, $72 \%$ of the studies under consideration were conducted without any reference to the GTI. Most of these assessments were initiated in an academic context (49\%). Studies initiated by the GTI come only second $(28 \%)$, followed by government requests (22\% of the corpus). The academic and government studies were homogenous over time (Fig. 1A), whereas the GTI studies focused primarily on the 1999-2007 period.

This period corresponds to the momentum generated by the $\mathrm{CBD}$ decisions and the coordination mechanism of the GTI. The 2004 peak relates to the presentations made at the GTI symposium on the island of Vilm, Germany. The GTI studies have a somewhat informal format, such as communications, interim documents and online articles (Fig. 1A); the GTI was apparently not the driving force behind those evaluations. Evaluations of taxonomy are, therefore, the result of a fragmented mobilisation through several sporadic and independent initiatives (see collaboration networks in Fig. 1B).

\section{National dynamics better explain the origin of taxonomic evaluations}

As displayed on the map in Fig. 2, authors from developed countries contributed $82 \%$ of the documents, authors from 
developing countries contributed 28\% and those from Brazil, Russia, India, China and South Africa (the BRICS) contributed $15 \%$ of the studies (co-authorship by authors from, for example, developed and developing countries of the same research accounts for the breakdown equalling $>100 \%$ ). Authors from megadiverse countries (as defined by UNEP; Mittermeier and Goettsch Mittermeier 1997) were present in $39 \%$ of the studies.

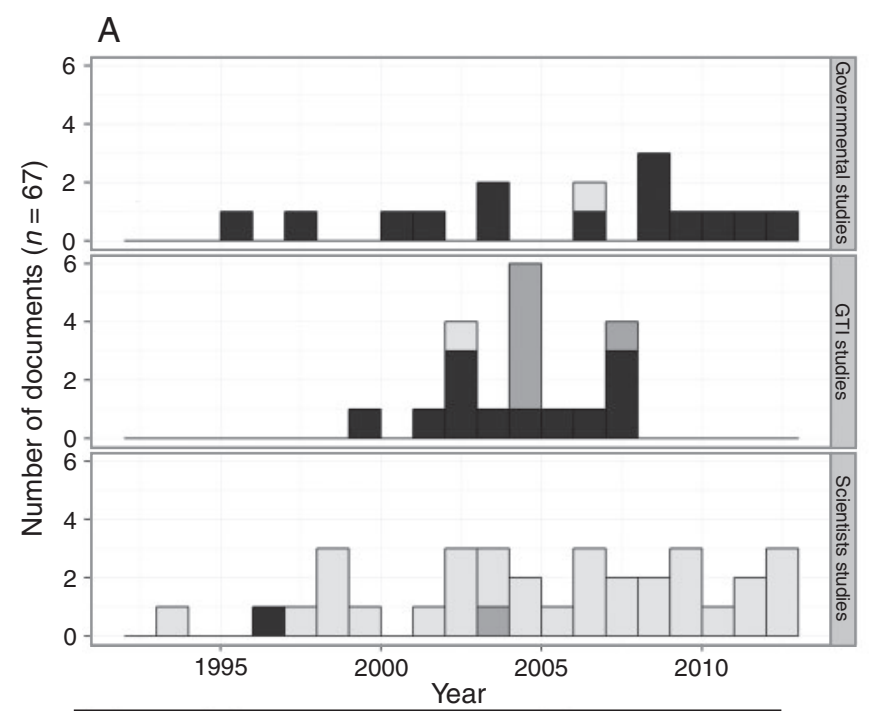

Report $\square$ Web \& Meeting communication $\square$ Peer-reviewed paper
Authors that are the most actively involved in the practice of taxonomic assessment, therefore, belong to countries with two distinct profiles. On the one hand, there are countries that developed their capacities in the 19th century, mostly during their colonial expansion (the United Kingdom and France in particular; McClellan and Regourd 2000; Hine 2008; Figueiredo and Smith 2010), and whose academic production in the area of taxonomy is now declining (Tancoigne et al. 2011; Dumoulin

\section{B}

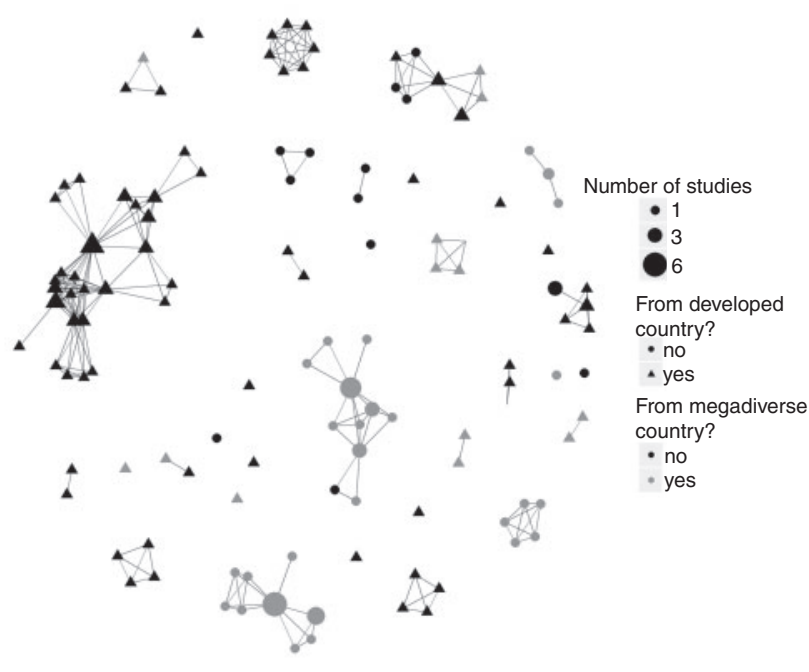

Fig. 1. A. Bar graph of the places undertaking research on taxonomic effort through time. B. Collaboration network of the authors of research on taxonomic effort. Shading and shape of the node indicate the authors' working place. Size of the node indicates the number of studies they published on taxonomic effort.
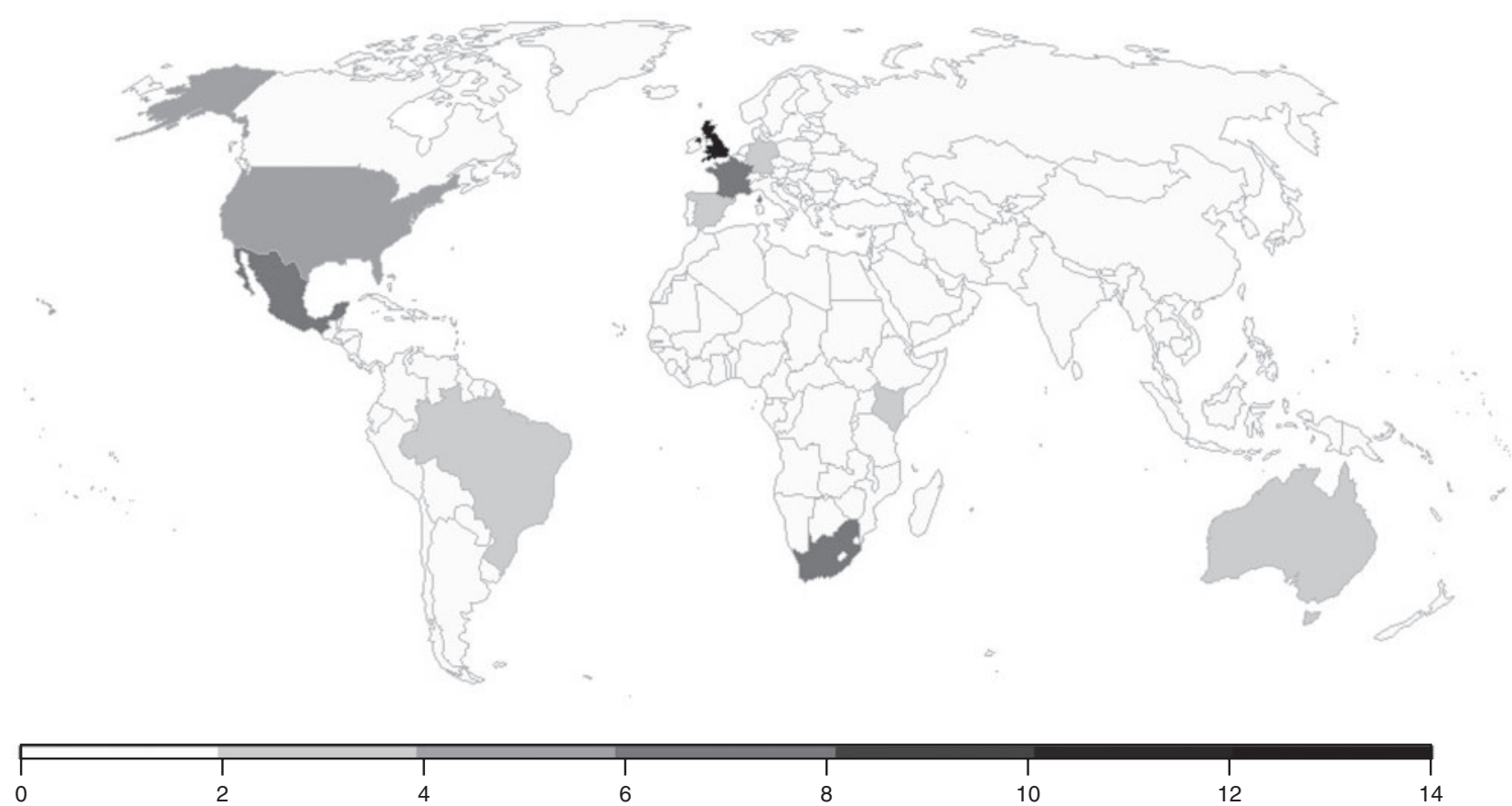

Fig. 2. Distribution of studies by authors' countries. The darker a country, the higher the number of authors assessing taxonomy. 
and Ollivier 2013). On the other hand, other assessments concern economically emerging countries that have a great wealth of biological diversity in their territory and view its protection and management as a political mission (e.g. Mexico, Brazil, and South Africa), particularly through the CBD. Those assessments are mainly the work of previous 'taxonomic powers', as well as some countries that have a great wealth of biological diversity in their territory and view conservation of biodiversity as a political objective. National dynamics, therefore, better explain the origin of these evaluations than does the GTI.

\section{Limited sources of data and imbalanced geographical coverage}

In spite of a few attempts by some actors (i.e. the World Taxonomist Database), there are, at present, no complete resources on which to base detailed measures of the demography, resources or activity of taxonomists. Sources mostly include questionnaires based on directories or acquaintanceship networks (42\% of the studies), bibliographical databases (28\%) and, last, various databases on biodiversity (15\%: inventories, publications, catalogues). This situation explains the rather limited scope of these assessments, namely, $90 \%$ of the studies deal only with a single taxon, a single geographical area or both. The European (28\%) and megadiverse $(27 \%)$ countries are the most frequently cited, followed by the world as a whole (24\% of the studies). A comparison of this geographical distribution with the mapping of newly discovered species realised by Grieneisen et al. (2014) shows a clear geographical imbalance. For instance, China, India and Madagascar belong to the most studied countries (in terms of species discovery), but they have no assessment records of their taxonomic capacities. On the contrary, the United Kingdom is extensively monitored; however, few new species are discovered there each year. One can, therefore, conclude that there are as yet no appropriate sources, nor appropriate coverage of the places where (at least some of the) taxonomic activities occur.

\section{A focus on species description}

What indicators do we use to assess taxonomy? At first sight, the indicators look very diverse (Fig. 3). Demographic indicators come first $(70 \%)$, followed by taxonomic-activity indicators $(66 \%)$ and, last, come resources indicators (46\%).

The most frequent demographic metric concerns the number of taxonomists (58\% of the studies). This is not surprising,

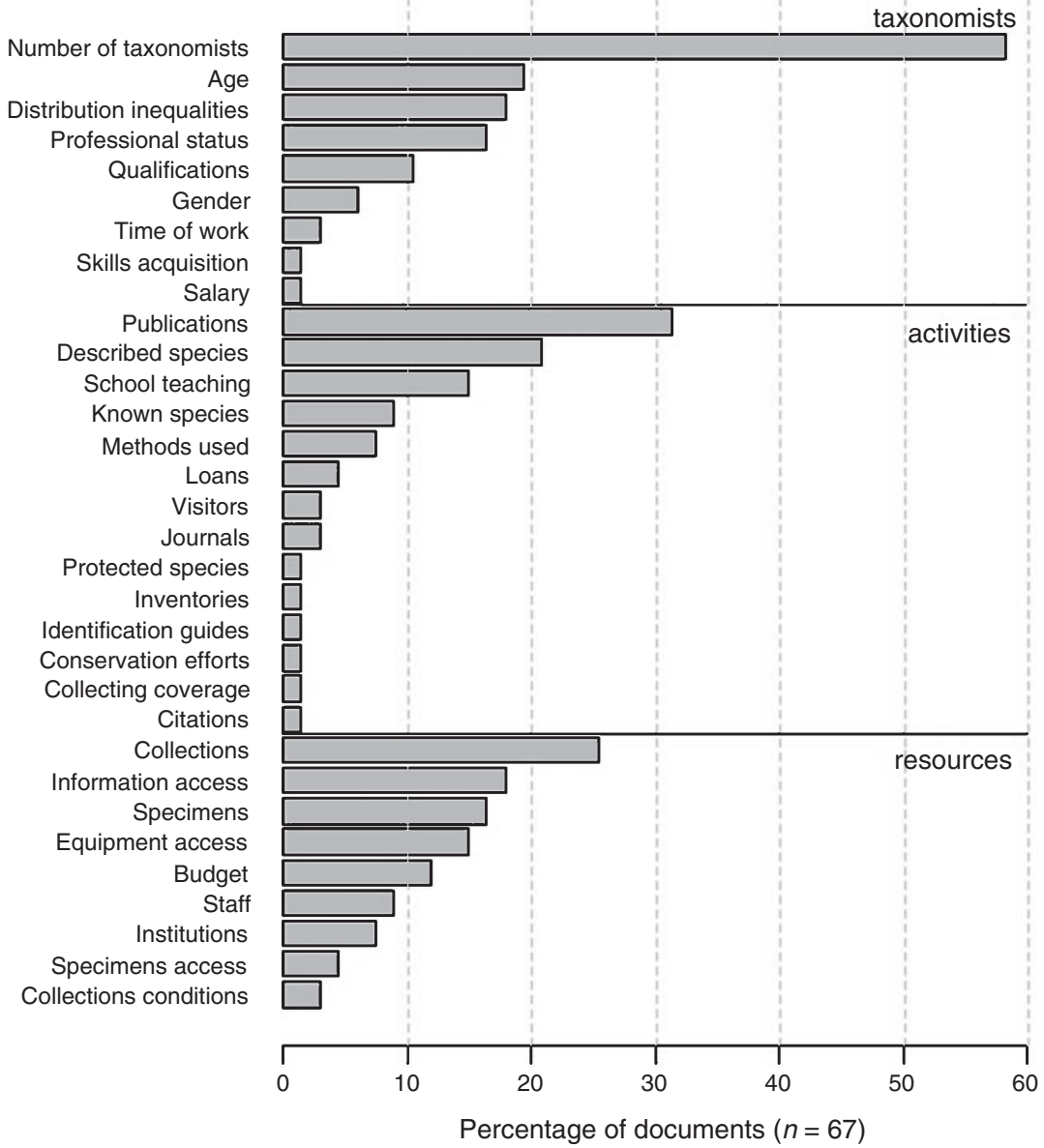

Fig. 3. Indicators used in quantitative assessments of the demography, activity and resources of taxonomy. 
given the frequent concerns expressed that taxonomists are facing extinction (e.g. Hopkins and Freckleton 2002). Other indicators include age, professional status (i.e. holding office or not) and level of education, as well as questions about their distribution across taxonomic groups worked on and countries in which they work. Activity indicators mainly record the number of publications and new species descriptions. Resource indicators represent, for the most part, the number of collections and specimens, access to the collections and their information, or access to high-quality equipment.

However, despite their apparent heterogeneity, the main indicators (i.e. number of taxonomists, number of publications, number of collections, number of described species) actually refer back to a single activity, the description of species. Taxonomists and publications are retrieved in databases with keywords on the basis of their participation to the speciesdescription enterprise (e.g. 'sp. nov.', 'new species'). Taxonomy is, therefore, mostly evaluated through its activity of species description. The indicators that are used do not reflect the vision that we presented early on, namely that 'far beyond discovering and naming new species, taxonomy is driven by evolutionary hypotheses that generate predictive classifications and improve our understanding of biotic diversity through meticulous systematic revisions and homology assessments' (de Carvalho et al. 2014, p. 323).

\section{Evaluations performed by a majority of end-users of taxonomy}

We wondered whether this narrowing of taxonomy to species descriptions and nomenclature could be explained by the disciplines of the authors, as was previously stated by de Carvalho et al. (2014). Interestingly, only 2 of 123 authors have stated in their online biographies that they describe species, and a minority (25\%) use the term 'taxonomy' to describe themselves, always in combination with words such as systematics, evolution, ecology or conservation. Therefore, most of the professional scientists $(89 \%$ of the authors of our corpus hold an office) that are involved in these assessments do not formally recognise themselves as 'taxonomists' or 'species descriptors'. The largest category of authors comprises users of taxonomy or disciplines where taxonomy is only one approach among others (41\%). This includes ecologists and biologists in the field of conservation (26\%), agronomy, palaeontology and botany $(15 \%)$. Then come systematists (phylogeneticists and taxonomists, $17 \%$ each). The smallest category of authors covers the observers of taxonomy, namely methodologists (statisticians, bibliometricians and sociologists: $8 \%$ ) or policy administrators (7\%).

However, does it mean that end-users tend to see only the descriptive side of taxonomy? We checked the kind of definitions that authors provided for taxonomy (64\% of the documents provided a definition). We found that the opposite was true, i.e. they expanded the practices of taxonomy beyond species description. A majority of the definitions (57\%) was either close to the definition of taxonomy provided by de Carvalho et al. (2014), or closer to a broader kind of definition, that could be qualified as 'romantic' (e.g. 'taxonomy is the pioneering exploration of life on a little-known planet';
Wilson 2004). One can, therefore, conclude that the indicators used to evaluate taxonomy do not reflect their authors' views on taxonomy, nor do they reflect their actual own practices.

\section{Discussion}

\section{Going beyond species description}

We showed, in Fig. 3 and its accompanying commentary, that there are no appropriate sources of data on taxonomic activities, resources or demographics of taxonomy. Neither are there appropriate indicators that reflect the activities and needs of the field, as defined by us, or by the assessors themselves. Must we conclude that focusing on the rate of species description is totally inappropriate? If we consider the species as the basic unit of work in taxonomy, measuring the description of species activity numerically would be the best way to evaluate it. Moreover, there are pragmatic reasons to focus on the number of species described, given that keywords such as 'sp. nov.' or 'new species' are used to retrieve information in databases. Finally, one could also argue that these evaluations are made with conservation purposes (e.g. 90\% refer to the notion of taxonomic impediment and 64\% reiterate the importance of taxonomy for conservation). Species description could be a good indicator with regard to the goals of the CBD. However, despite these three arguments, we state that it is clearly not.

\section{Why should we go beyond species description?}

Tancoigne (2011) showed that only $2 \%$ of the zoological names present in the Index to Organism Names were used in conservation studies indexed in the Zoological Record, which means that $99.8 \%$ of the names were not used for conservation studies. However, what this 2011 study indicated is the importance of distributional data to connect taxonomy and other scientific fields (Tancoigne 2011, p. 81). Other scientific disciplines do not use species descriptions, nor do they use species names extensively. However, they do use (and cite) the distributional data that are provided by taxonomists. Moreover, fewer than 80000 species are monitored by the International Union for the Conservation of Nature (IUCN), which is far fewer than the 1900000 estimated described species (Chapman 2009). Therefore, focusing on distributional data or identification keys provided by taxonomists would be much more appropriate to evaluate the progress on biodiversity knowledge needed for conservation today. This is not to say that taxonomists should publish distributional data instead of new species descriptions. Of course, descriptions are needed to get accurate checklists. However, the question is whether the number of species described alone is the best indicator of taxonomic activity.

A second argument addresses the quality of the information produced. One might wish to evaluate not only the quantity, but also the quality of the information produced by taxonomists on biodiversity. Is a single description of a species as valuable as a description published in a taxonomic revision? A good taxonomic revision might need 10 years to achieve, with few new described species at the end. In this case, assessing revisions would be a better way to evaluate the activity and needs of taxonomy. The question 'How many species have been 
described in this group?' would become 'When was this group last revised?'.

However, we do not stand for an evaluation of taxonomy based on the distributional data it produces, or its diagnostic keys, or its revisions. The third criticism is based on the nature of the main data used to assess taxonomy, namely species descriptions. Species descriptions are an output of taxonomy (like distributional data, diagnostic keys, revisions, or phylogenies and synonyms). Yet, output indicators are not fit to evaluate the needs of taxonomy, as required by the GTI. These needs are the result of a disjunction between an aim (i.e. preserving biodiversity before it disappears) and the resources devoted to it. Focusing on a particular type of output is, therefore, insufficient with regard to the objectives of the GTI. It will always require coupling to measures of resources.

The last argument takes another point of view. Instead of arguing that counting numbers of species described is not the best choice to fit the CBD goals, we argue that focusing on species per se might turn into a weakness if the CBD framing changes. There is a groundswell of opinion, both in the scientific and political spheres, that suggests breaking with the compositional approach in favour of a functionalist approach (Callicott et al. 1999) for biodiversity management and conservation. Whereas the compositional approach requires identification of the species in an ecosystem, the functional approach requires knowledge of their functional traits. This transition is particularly noticeable, given the considerable importance to the notion of ecosystem services in the scientific literature (Tancoigne et al. 2014) and to the Millennium Ecosystem Assessment (Hassan et al. 2005) in the political agenda. This has led to the creation of a new international body, complementary to the CBD, namely the Intergovernmental Science-Policy Platform on Biodiversity and Ecosystem Services (IPBES, Vadrot 2014). In this context, precise species identification might not become the most essential element. By changing the legitimate knowledge register so as to satisfy conservation requirements, the movement supporting ecosystem services may relegate taxonomists to 'mere data providers for nature managers and ecologists interested in ecosystem functioning' (Granjou et al. 2014, p. 254), being precisely what taxonomists are trying to avoid (de Carvalho et al. 2014).

Resisting focusing on species description to evaluate taxonomy might, therefore, be a strategy to defend taxonomy from a taxonomist perspective. This is not to say that one should stop counting the number of described species, but rather that one should not use this metric when it comes to evaluate taxonomy. What would be a viable alternative? Our paper cannot provide a turn-key solution to this question. However, we propose two paths, namely

(1) new types of indicators, and

(2) a new set of actors that would be in charge of these evaluations.

\section{Towards a new set of indicators}

We need to find an indicator that (1) meaningfully assesses the knowledge available for conservation goals, (2) adequately evaluates the needs in the context of the taxonomic impediment,
(3) could be standardised across countries and places, (4) uses worldwide sources of data and (5) is robust and stable enough to resist any change in taxonomic research practices on the long run.

Taxonomic collections housed in herbaria and museums have been an unquestioned invariant of taxonomic research. They are available worldwide, are a source of knowledge on taxonomic capacities, and they provide distributional data. Collections have been a necessary gateway to any kind of taxonomic research since (and even before) Linneaus. They are an essential feature of any taxonomic activity (Suarez and Tsutsui 2004; Szwedo and Iwan 2008; Hoberg et al. 2009), and are, therefore, often used to sound the alarm about its decline (Holden 1985; Dalton 2003; Gropp 2003; Miller et al. 2004; Paknia et al. 2015). Collection data are more and more being digitised (Scoble and Bourgoin 2010; Smith and Blagoderov 2012; Orli and Bird 2016). Questions that indicators on collections can potentially answer, address both the needs and activities of taxonomy and include the following, for example: what places have not been sampled; where is most of the taxonomic activity physically located; what are the specimens that have not been identified; what are the specimens that have not been revised; and what amount of staff is devoted to collections? Collections are already at the interface of science and policy (National Science and Technology Council, Committee on Science, Interagency Working Group on Scientific Collections 2009; Office of the Inspector General 2009). For all these reasons, we therefore suggest evaluating taxonomy through collectionbased indicators.

We noted that a few indicators used in the assessments evaluated here already refer to collections. However, most refer to either their numbering, or the numbering of collected specimens; this is not sufficient to establish how much we know about biodiversity, nor how much taxonomy is supported. A new set of indicators is needed. We propose to enrich the existing indicators with measures on (1) the resources of collections (e.g. number of specimens, available staff, number of species identified), (2) their activities (e.g. number of new specimens collected per year, yearly loans, and visiting scholars), (3) their resolution rate (e.g. proportion of unstudied specimens, proportion of specimens that have been revised) and, last, (4) another set of indicators related to taxonomic, geographic and temporal coverage, including surveyed areas, studied groups, years of collect. These two types of indicators (activity, coverage) could help monitor both the activity and needs of taxonomy. Knowing, for instance, that some specimens have not been revised for the past 100 years, or that one technician curates 1 million specimens in one city $v$. 5 million in another, is the first step in taking informed decisions about where to put taxonomic efforts.

Of course, a great amount of work has already been conducted on this subject and some of the proposed indicators are already used (see, for instance, the excellent report by Hamer and Raath 2011). However, they are often used only internally, within museums and taxonomic research institutions. They are not publicly released, nor in a comparable format. Because collections are not homogeneous across countries or taxa, a set of harmonised metrics have to be developed to perform comparisons. 


\section{Who would be in charge?}

We show here (Fig. 1 and associated commentary) that the GTI, a dedicated international platform, has not played a leading role in the quantitative assessments of taxonomy. No long-lasting collective has been created on this question, nor have data sources and methods been centralised or standardised. What has hampered this initiative? There are several explanations. First, many countries have difficulties in allocating funds or in considering this subject a priority. Some comments of the national reports issued for the $\mathrm{CBD}$ and in the framing material of the GTI have noted this lack of funding for proper assessment, and the COP decision VIII/18 2006 called for Global Environment Fund investments to support national operators. A second explanation is structural. Samper (2004) noted that some CBD delegates perceived the GTI primarily as an initiative led by scientists, with no clear link to the overall structure and objectives of the CBD. Dumoulin and Ollivier (2013) also showed that the GTI is the result of the mobilisation of some researchers (since the 1986 Forum of Washington to the 1998 Darwin Declaration (Environment Australia 1998) through the Systematics Agenda 2000 (1994)) to recognise the taxonomic impediment within the CBD. This cleavage could have contributed to the lack of consideration of issues of taxonomy by political representatives in the CBD and national administrations. Finally, the heterogeneity and short life of GTI assessments can be linked to the current shift occurring in the GTI (and CBD more broadly) towards barcoding and big data as a technological solution to the taxonomic impediment. Initially, shyly raised in the GTI (first occurrence in 2005), these technologies, and their associated environments, have gradually gained prominence, in particular with the 2010 Nagoya Protocol. As evidenced by the many co-investments and cross invitations to conferences and side events of the CBD (Schindel et al. 2009; Waterton et al. 2013), proponents of barcoding have actively integrated the CBD, BioNET International (the Global Network for Taxonomy created to promote developing countries' taxonomical autonomy) and the GTI.

The GTI, therefore, does not seem the right place to support the assessment of taxonomy. What is a possible solution to offer, then? Another interesting result from our study is that taxonomists are marginally involved in these assessments. What we suggest is to draw on collectives that gather people working with collections, especially those who curate and monitor them. Societies such as The Society for The Preservation of Natural History Collections (SPNHC), The Natural Sciences Collections Association (NatSCA) or The Natural Science Collections Alliance (NSC) are examples of such collectives (for the English-speaking countries). Working groups are also already established within the GBIF (Ariño 2010; Berendsohn et al. 2010). Building on existing collectives and their long-lasting expertise would probably prove more useful than would working within the GTI for one-shot evaluations. These new indicators, based on collections instead of described species (resources, activities, resolution rate and coverage), could join up with other biodiversity data, such as the data curated by the Global Biodiversity Information Facility (Berendsohn et al. 2010), contributing to the first online observatory for the monitoring of taxonomy. Maybe a new verse would then emerge for the wellknown hit of the extinction of taxonomy.

\section{Conclusions}

Our study raised the following four main criticisms concerning the indicators that we use to assess taxonomy today: (1) they focus on the outputs of taxonomy, not its resources; (2) they focus on the wrong output; (3) they assess the quantity, not the quality of the work produced; and (4) they might not resist a paradigm shift in international biodiversity politics. We propose to enrich the existing indicators with measures on taxonomic collections, such as (1) the resources of taxonomic collections (e.g. number of specimens, available staff, number of species identified), (2) their activities (e.g. number of new specimens collected per year, yearly loans, and visiting scholars), (3) their resolution rate (e.g. proportion of unstudied specimens, proportion of specimens that have been revised) and (4) their taxonomic, geographic and temporal coverage, including surveyed areas, studied groups, years of collection. Building this new set of indicators will require the collaboration and expertise of the collectives that work on collections in regional and national contexts, outside the CBD.

\section{Conflicts of interest}

The authors declare that they have no conflicts of interest.

\section{Acknowledgments}

We gratefully thank Alain Dubois, along with the ReptAmph laboratory at the Paris Museum of National History. We are also grateful to Sarah Samadi, Laure Corbari and Gabriela Sanchez for their valuable help. Aurélien Miralles, Florence Revelin, Thomas Tari, Marianne Noël, Ashveen Peerbaye, Susanne Renner, Bruno Strasser, Sandra Goutte, Miranda Gray provided critical insights into the earlier drafts of this work. We finally thank Cassandra Delacôte for the English translation of our first draft, the editors and the anonymous reviewers for their careful reading and helpful suggestions. This work was supported by the French Ministry of Education and Research (PhD grant to E. Tancoigne), the French National Agency for Research (project ExpéBiodiv), and the UMR Lisis.

\section{References}

Advisory Board for the Research Councils (1979) Taxonomy in Britain. Report by the Review Group on Taxonomy set up by the Advisory Board for the Research Councils under the chairmanship of Sir Eric Smith, Her Majesty's Stationery Office, London, UK.

Ariño AH (2010) Approaches to estimating the universe of natural history collections data. Biodiversity Informatics 7(2), 81-92. doi:10.17161/bi.v7i2.3991

Balcells E (1963) 'Sugerencias y aspectos de labor zoologica en Espana.' (Comisión de Estudios Zoológicos, Madrid, Spain)

Berendsohn WG, Chavan V, Macklin J (2010) Summary of recommendations of the GBIF task group on the global strategy and action plan for the digitisation of natural history collections. Biodiversity Informatics 7(2), 61-71. doi:10.17161/bi.v7i2.3989

Blackwelder RE (1959) The present status of systematic zoology. Systematic Zoology 8, 69-75. doi:10.2307/2411766

Brues CT (1939) Some adaptive responses of taxonomy to a changing environment. Journal of the New York Entomological Society 47(2), $145-154$. 
Callicott JB, Crowder LB, Mumford K (1999) Current normative concepts in conservation. Conservation Biology 13, 22-35. doi:10.1046/j.1523-1739.1999.97333.x

Chapman AD (2009) Numbers of living species in Australia and the world. Report for the Australian Biological Resources Study, Australian Biological Resources Study, Canberra, ACT, Australia.

Costello MJ, May RM, Stork NE (2013) Can we name Earth's species before they go extinct? Science 339, 413-416. doi:10.1126/science. 1230318

Dalton R (2003) Natural history collections in crisis as funding is slashed. Nature 423, 575. doi:10.1038/423575a

de Carvalho MR, Ebach MC, Williams DM, Nihei SS, Trefaut Rodrigues M, Grant T, Silveira LF, Zaher H, Gill AC, Schelly RC, Sparks JS, Bockmann FA, Séret B, Ho H-C, Grande L, Rieppel O, Dubois A, Ohler A, Faivovich $\mathrm{J}$, Assis LCS, Wheeler QD, Goldstein PZ, de Almeida EAB, Valdecasas AG, Nelson G (2014) Does counting species count as taxonomy? On misrepresenting systematics, yet again. Cladistics 30, 322-329. doi:10.1111/cla.12045

Dumoulin D, Ollivier G (2013) Comment peut-on être systématicien? Faire exister une communauté scientifique : le cas français dans la dynamique internationale. Revue d'Anthropologie des Connaissances 7, 365-410. doi:10.3917/rac.019.0365

Edwards SR, David GM, Nerling L (1985) 'The Systematics Community.' (Association of Systematics Collections c/o Museum of Natural History, University of Kansas: Lawrence, KS, USA)

Environment Australia (1998) The Darwin Declaration. Australian Biological Resources Study and Environment Australia, Canberra, ACT, Australia.

Figueiredo E, Smith GF (2010) The colonial legacy in African plant taxonomy. South African Journal of Science 106. doi:10.4102/sajs.v106i3/4.161

Fontaine B, van Achterberg K, Alonso-Zarazaga MA, Araujo R, Asche M, Aspöck H, Aspöck U, Audisio P, Aukema B, Bailly N, Balsamo M, Bank RA, Belfiore C, Bogdanowicz W, Boxshall G, Burckhardt D, Chylarecki P, Deharveng L, Dubois A, Enghoff H, Fochetti R, Fontaine C, Gargominy O, Lopez MSG, Goujet D, Harvey MS, Heller K-G, van Helsdingen P, Hoch H, De Jong Y, Karsholt O, Los W, Magowski W, Massard JA, McInnes SJ, Mendes LF, Mey E, Michelsen V, Minelli A, Nafria JMN, van Nieukerken EJ, Pape T, De Prins W, Ramos M, Ricci C, Roselaar C, Rota E, Segers H, Timm T, van Tol J, Bouchet P (2012) New species in the Old World: Europe as a frontier in biodiversity exploration, a test bed for 21 st century taxonomy. PLoS One 7(5), e36881. doi:10.1371/journal.pone.0036881

Granjou C, Mauz I, Barbier M, Breucker P (2014) Making taxonomy environmentally relevant. Insights from an all taxa biodiversity inventory. Environmental Science \& Policy 38, 254-262. doi:10.1016/j.envsci.2014.01.004

Grieneisen ML, Zhan Y, Potter D, Zhang M (2014) Biodiversity, taxonomic infrastructure, international collaboration, and new species discovery. Bioscience 64(4), 322332. doi:10.1093/biosci/biu035

Gropp RE (2003) Are university natural science collections going extinct? Bioscience 53, 550. doi:10.1641/0006-3568(2003)053[0550:AUNSCG]2.0.CO;2

Hamer M, Raath M (2011) Audit report of South Africa's Natural Science Collections. Collecting now to preserve the Future. Totem Media, Johannesburg, South Africa; and South African National Biodiversity Institute, Pretoria, South Africa.

Hassan R, Scholes R, Ash N (Eds) (2005) 'Ecosystems and Human Wellbeing: Current State and Trends, The Millennium Ecosystem Assessment Series.' (Island Press: London, UK)

Hebert PDN, Gregory TR (2005) The promise of DNA barcoding for taxonomy. Systematic Biology 54, 852-859.

doi:10.1080/10635150500354886
Hine C (2008) 'Systematics as Cyberscience: Computers, Change, and Continuity in Science', Inside Technology series. (MIT Press: Cambridge, MA, USA)

Hoberg EP, Pilitt PA, Galbreath KE (2009) Why museums matter: a tale of pinworms (Oxyuroidea: Heteroxynematidae) among pikas (Ochotona princeps and $O$. collaris) in the American West. The Journal of Parasitology 95, 490-501. doi:10.1645/GE-1823.1

Holden C (1985) Princeton to give up its fossils. Science 228, 38. doi: $10.1126 /$ science. 228.4695 .38

Hopkins GW, Freckleton RP (2002) Declines in the numbers of amateur and professional taxonomists: implications for conservation. Animal Conservation 5, 245-249. doi:10.1017/S1367943002002299

Janzen DH (1993) Taxonomy: universal and essential infrastructure for development and management of tropical wildlands biodiversity. In 'Proceedings of the Norway/UNEP Expert Conference on Biodiversity', 24-28 May 1993, Trondheim, Norway. (Eds OT Sandlund, PJ Schei) pp. 100-113. (Directorate for Nature Management and Norwegian Institute for Nature Research: Trondheim, Norway)

Joppa LN, Roberts DL, Pimm SL (2011) The population ecology and social behaviour of taxonomists. Trends in Ecology \& Evolution 26, 551-553. doi:10.1016/j.tree.2011.07.010

La Salle J, Wheeler Q, Jackway P, Winterton S, Hobern D, Lovell D (2009) Accelerating taxonomic discovery through automated character extraction. Zootaxa 2217, 43-55.

McClellan JE III, Regourd F (2000) The colonial machine: French science and colonization in the Ancien regime. Osiris 15, 31-50. doi:10.1086/649317

Michán Aguirre L, Llorente Bousquets JE (2003) La taxonomía en méxico durante el siglo XX. Publicaciones Especiales del Museo de Zoología 12, $1-229$.

Michán Aguirre L, Llorente Bousquets JE (2010) Bibliometría de la sistemática biológica sobre América Latina durante el siglo XX en tres bases de datos mundiales. Revista de Biología Tropical 58, 531-545.

Michán Aguirre L, Llorente Bousquets JE, Martínez AL, Castro DJ (2004) Breve historia de la taxonomía de Lepidoptera en México durante el siglo XX. In 'Biodiversidad, Taxonomía y Biogeografía de Artrópodos en México: Hacia una síntesis de su conocimiento'. (Eds JE Llorente Bousquets, JJ Morrone, O Yáñez Ordóñez, I Vargas Fernández) Vol. IV, pp. 5-42. (Universidad Nacional Autónoma de México: Mexico City, México)

Michán Aguirre L, Russell JM, Sanchez Pereyra A, Llorens Cruset A, Beltrán CL (2008) Análisis de la sistemática actual en Latinoamérica. Interciencia 33, 754-761.

Miller SE, Kress WJ, Samper CK (2004) Crisis for biodiversity collections. Science 303, 310. doi:10.1126/science.303.5656.310b

Mittermeier RA, Goettsch Mittermeier C (1997) 'Megadiversity: Earth's Biologically Wealthiest Nations.' (CEMEX: Mexico City, Mexico)

National Science and Technology Council, Committee on Science, Interagency Working Group on Scientific Collections (2009) 'Scientific Collections: Mission-Critical Infrastructure of Federal Science Agencies.' (Office of Science and Technology Policy: Washington, DC, USA)

Office of the Inspector General (2009) 'Museum Collections: Accountability and Preservation.' (US Department of the Interior: Washington, DC, USA)

Orli S, Bird J (2016) Establishing workflows and opening access to data within natural history collections. Collections 12, 147-162.

Paknia O, Sh HR, Koch A (2015) Lack of well-maintained natural history collections and taxonomists in megadiverse developing countries hampers global biodiversity exploration. Organisms, Diversity \& Evolution 15, 619-629. doi:10.1007/s13127-015-0202-1 
Ride WDL, McCusker A (1978) 'Australian Biological Resources Study, 1973-78.' (Australian Government Publishing Service: Canberra, ACT, Australia)

Saldaña J (2012) 'The Coding Manual for Qualitative Researchers.' (SAGE Publications: Los Angeles, CA, USA)

Samper C (2004) Taxonomy and environmental policy. Philosophical Transactions of the Royal Society of London. Series B, Biological Sciences 359, 721-728. doi:10.1098/rstb.2004.1476

Schindel DE, Haeuser C, Miller SE, Bavikatte K, Beck E, Burks C, Davies N, Desmeth P, du Plessis P, Garrity G, Geeta R, Haas F, Holm-Mueller K, Huntley B, Chege Kamau E, Kim W, Lyal CHC, Marinoni L, Martinez S, Matsuura K, Ni KJ, Ong P, Schönwitz R, Wahiche JD (2009) Preserving international access to genetic resources for non-commercial biodiversity research. Report from the International Workshop on Access and Benefit Sharing in Non-Commercial Research, 17-19 November 2008, Museum Koenig, Bonn, Germany.

Scoble MJ, Bourgoin T (2010) Natural history collections digitization: rationale and value. Biodiversity Informatics 7, 77-80. doi:10.17161/bi.v7i2.3994

Smith V, Blagoderov V (2012) Bringing collections out of the dark. ZooKeys 209, 1-6. doi:10.3897/zookeys.209.3699

Suarez AV, Tsutsui ND (2004) The value of museum collections for research and society. Bioscience 54, 66-74. doi:10.1641/0006-3568(2004)054[0066:TVOMCF]2.0.CO;2

Systematics Agenda 2000 (1994) Systematics Agenda 2000: Charting the Biosphere. Technical report, Systematics Agenda, New York, NY, USA.
Szwedo J, Iwan D (2008) To survive or to flourish? Status and role of natural history museums in the biodiversity research. Polish Taxonomical Monographs 15, 55-69.

Tancoigne E (2011) Evaluer la santé de la taxonomie zoologique: histoire, méthodes et enjeux contemporains. PhD thesis, National Museum of Natural History, Paris, France. Available at https://tel.archives-ouvertes. fr/tel-00707531 [Verified 12 October 2017]

Tancoigne E, Bole C, Sigogneau A, Dubois A (2011) Insights from zootaxa on potential trends in zoological taxonomy. Frontiers in Zoology 8(1), 5. doi:10.1186/1742-9994-8-5

Tancoigne E, Barbier M, Cointet J-P, Richard G (2014) The place of agricultural sciences in the literature on ecosystem services. Ecosystem Services 10, 35-48. doi:10.1016/j.ecoser.2014.07.004

Vadrot ABM (2014) 'The Politics of Knowledge and Global Biodiversity.' (Routledge: New York, NY, USA)

Waterton C, Ellis R, Wynne B (2013) 'Barcoding Nature: Shifting Cultures of Taxonomy in an Age of Biodiversity Loss.' (Routledge: London, UK)

Weeks PJD, Gaston KJ (1997) Image analysis, neural networks, and the taxonomic impediment to biodiversity studies. Biodiversity and Conservation 6, 263-274. doi:10.1023/A:1018348204573

Wilson EO (2004) Taxonomy as a fundamental discipline. Philosophical Transactions of the Royal Society of London - B. Biological Sciences 359, 739. doi: $10.1098 /$ rstb.2003.1440 


\section{Appendix 1. Identifying the documents}

We gathered quantitative assessments from a broad range of sources. We searched on academic reference libraries (Web of Science, Scopus, Zoological Record), the publisher platform JSTOR, and digital book libraries (Google Books, Biodiversity Heritage Library, Internet Archive, Hathi Trust Digital Library, Gallica, Europeana). We searched the Global Biodiversity Information Facility (GBIF), European Distributed Institute of Taxonomy (EDIT) and Convention on Biological Diversity (CBD) websites. We also conducted a web search on Google using several requests (e.g. '(progress) AND (taxonom*)'). We sent an email request for literature to all members on the mailing list Taxacom (Richard Zander, University of Kansas, http://taxacom.markmail.org/) in March 2011. We also contacted many of the authors of the main GTI reports so as to obtain up-to-date documents or documents unavailable online. Finally, we conducted an iterative search in the references of the retrieved corpus so as to enlarge it. We then sorted these documents, retaining only the documents that presented original information on taxonomic quantification. We excluded from our analysis documents containing species description curves (graphs) for the purposes of biodiversity assessment, documents dealing with the problems of citation in taxonomy or documents re-using previously published data. The comprehensiveness of our corpus can be assessed by browsing the Supplementary material.

\section{Appendix 2. Describing the assessments}

We described both the documents and their authors.

\section{Variables describing the documents}

We described the documents with the following variables: year of publication, type of document, type of journal, number of authors', lead author's region and study coverage for the geographical and taxonomical coverage (see Table A1). Then, we described the content of each document according to the following four variables (when available): context of the study, definition of taxonomy, importance of taxonomy and methods used (see Table A1). The variable 'importance of taxonomy' appeared during the analysis; we found that a lot of studies spent one or two lines of text to justify why taxonomy should be supported. We found it interesting to analyse the different reasons provided. Overall, we ended with 10 variables describing the documents (see Table A1).

Table A1. List of variables and their modalities identified for each document

\begin{tabular}{|c|c|}
\hline Variable & Modality \\
\hline Year $^{\mathrm{A}}$ & 1992-2012 \\
\hline Origin of document ${ }^{\mathrm{B}}$ & 'National report' or 'GTI report' or 'scientific study' \\
\hline Disciplines of journal $^{\mathrm{B}}$ & 'Biology' or 'general' or 'ecology \& conservation' or 'taxonomy \& systematics' \\
\hline Number of authors ${ }^{\mathrm{A}}$ & Between 0 and 51 \\
\hline Study coverage ${ }^{\mathrm{A}}$ & 'Worldwide' or 'geographically limited' or 'taxonomically limited' or 'both limitations' \\
\hline Context of the study ${ }^{\mathrm{B}}$ & 'Progress review' or 'GTI-CBD' or 'taxonomic impediment' or 'other' \\
\hline Definition provided for taxonomy ${ }^{\mathrm{B}}$ & 'No definition' or 'narrow definition' or 'broad definition' or 'romantic' definition' \\
\hline Arguments for its support ${ }^{\mathrm{B}}$ & 'For human needs' or 'for other sciences' or 'for knowledge per se' \\
\hline Sources of data ${ }^{\mathrm{B}}$ & e.g. 'bibliographic databases', 'surveys' \\
\hline Indicators used ${ }^{\mathrm{B}}$ & e.g. 'number of taxonomists', 'number of described species', 'growth rate of collections'... \\
\hline & Classified into: 'demographic indicators' or 'activity indicators' or 'resources indicators' \\
\hline
\end{tabular}

${ }^{\mathrm{A}}$ Modality was defined a priori.

${ }^{\mathrm{B}}$ Modality was defined when reading the documents.

\section{Variables describing the authors of the documents}

We searched for information on the authors, such as, for example, 'country of residence', and 'specialty' (whether she or he is a taxonomist, a phylogeneticist, an ecologist. See their descriptions in Table A2). 
Table A2. List of variables and their modalities identified for each author

\begin{tabular}{|c|c|}
\hline Variable & Modality \\
\hline $\begin{array}{l}\text { Country of residence at the time of the } \\
\text { study }\end{array}$ & Any country of the world \\
\hline Professional status $^{\mathrm{A}}$ & 'Holding office' or 'not holding office' \\
\hline Country's level of development ${ }^{\mathrm{A}}$ & $\begin{array}{l}\text { 'Developed' or 'BRICS' (Brazil, Russia, India, China, South Africa) or 'developing or less } \\
\text { developed' }\end{array}$ \\
\hline Country's level of biodiversity ${ }^{\mathrm{A}}$ & 'Megadiverse' (UNEP definition) or 'not megadiverse' \\
\hline $\begin{array}{l}\text { Specialties mentioned online by the } \\
\text { author to define himself/herself } \\
\text { or to be introduced }^{\mathrm{B}}\end{array}$ & $\begin{array}{l}\text { e.g. 'taxonomist', 'biologist', 'biodiversity informatics', 'pest control' } \\
\text { Classified into: 'systematicians-phylogeneticists' or 'systematicians-taxonomists' or } \\
\text { 'methodologists' or 'ecologists-conservation biologists' or 'other users' or 'policy } \\
\text { makers' }\end{array}$ \\
\hline
\end{tabular}

${ }^{\mathrm{A}}$ Modality was defined $a$ priori.

${ }^{\mathrm{B}}$ Modality was defined when reading the documents.

We conducted online biographical research on each of the 123 authors of the 67 documents during the months of October and November 2012 and were able to find information on $~ 90 \%$ of them. In the case of reports, we retained only the coordinators, or the members of the committee responsible for the study. For an article comprising 51 authors (Fontaine et al. 2012), only the first five authors and the last author, as well as authors who appear elsewhere in the set of documents, were taken into account. We used the NVivo software dedicated to qualitative analysis (ver. 10, QSR International Pty Ltd, see https://www.qsrinternational.com/nvivo/ home). 


\section{Supplementary material}

\section{Evaluating the progress and needs of taxonomy since the Convention on Biological Diversity:}

going beyond the rate of species description

Elise Tancoigne $^{\mathrm{A}, \mathrm{B}, \mathrm{D}}$ and Guillaume Ollivier ${ }^{\mathrm{C}}$

Anstitut de Systématique, Evolution, Biodiversité, ISYEB - UMR 7205 CNRS MNHN UPMC EPHE, Muséum National d'Histoire Naturelle, 25 Rue Cuvier, F-75005 Paris, France.

${ }^{B}$ INRA, UMR Lisis, IFRIS, Université Marne-la-Vallée, Cité Descartes, Champs-sur-Marne, 5 Boulevard Descartes, F-77454 Marne-la-Vallée Cedex 02, France.

CINRA, UR0767 Ecodéveloppement, PACA Research Centre, Site Agroparc, CS40509, F-84914 Avignon Cedex 9, France.

${ }^{\text {DC }}$ Corresponding author. Present address: University of Geneva, Boulevard Carl Vogt 66, CH-1205 Geneva, Switzerland. Email: elise.tancoigne@unige.ch

\section{List of quantitative assessments of taxonomy $(1992-2012, n=84)$}

Documents analysed in our corpus $(\mathrm{n}=67)$

\section{GTI reports}

SBSTTA (1999); Herbert et al. (2001); Delanay and Associates (2002); Klopper et al. (2002); Shashikyan and Simonyan (2002); Wilson et al. (2002); Shimura (2003); Sattout (2004); Haas and Haeuser (2005, 2007); Taylor (2006); Anon. (2007); Oteng-Yeboah et al. (2007); Petř́k (2007); W. Bogdanowicz, unpubl. data, 2004; T. Bourgoin, unpubl. data, 2004; F. Haas, unpubl. data, 2004; T. Nikolić, unpubl. data, 2004; A. Silfvergrip, unpubl. data, 2004.

\section{Governmental studies}

Burnett et al. (1995); Shostak (1997); Tillier and De Wever (2000); Taylor and Hamer (2001); Götzl et al. (2003); Lewinsohn (2003); Australian Government Department of the Environment, Water, Heritage and the Arts (2006); Marques and Lamas (2006); Hall (2008); House of Lords, Science and Technology Committee (2008); Ng (2008); National Science and Technology Council, Committee on Science, Interagency Working Group on Scientific Collections (2009); Boxshall and Self (2011); Gerard et al. (2011); Lohrmann et al. (2012).

\section{Scientific studies}

Parnell (1993); Robles et al. (1996); Simonetti (1997); Green (1998); Sigogneau and Barriel (1998); Winston and Metzger (1998); Eggleton (1999); Herbert (2001); Hopkins and Freckleton (2002); Michán and Llorente (2002); Michán Aguirre and Morrone (2002); Michán Aguirre et al. (2004); Calabuig et al. (2003); Michán and Llorente Bousquets (2003, 2010); Cribb (2004); Löbl and Leschen (2005); Bouchet and Duarte (2006); Costello et al. (2006); McCallum and McCallum (2006); Agnarsson and Kuntner (2007); Pallini and 
Matiello Fadini (2007); Michán et al. (2008); Smith et al. (2008); O’Dogherty et al. (2009); Packer et al. (2009); Rodrigues et al. (2010); Joppa et al. (2011); Tancoigne et al. (2011); Bacher (2012); Fontaine et al. (2012); Hamer (2012); R. Geeta, A. Levy, J. M. Hoch and M. Mark, unpubl. data, 2003.

\section{Missing documents $(\mathrm{n}=17)$}

Schminke (1994, 1996); Hawksworth (1995); Simonetti et al. (1995); Visher (1995); Anon. (2004, 2005); Blackmore (1996); Ziegler et al. (1997); Asociación Colombiano De Herbarios (1999); Torres-Contreras (2001); Gleich et al. (2002); Herrera (2002); Gast and Krieger Rincón (2003); Legakis and Emblow (2003); Nangulah and Zeidler (2004); Office of the Inspector General (2009).

\section{References}

Agnarsson I, Kuntner M (2007) Taxonomy in a changing world: seeking solutions for a science in crisis. Systematic Biology 56(3), 531-539. doi:10.1080/10635150701424546

Anon. (2004) Actes (vol 1 et 2) Premier Atelier International de NAFRINET, 23-24 October 2003, Rabat, Morocco.

Anon. (2005) Mongolian and transboundary area biodiversity: natural resources, biodiversity and future ecological trends. In 'Mongolian and Transboundary Area Biodiversity: Natural Resources, Biodiversity and Future Ecological Trends', 2005, Ulaanbaatar, Mongolia.

Anon. (2007) Eléments de stratégie et plan d'action pour le renforcement des capacités dans le domaine de la taxonomie en République Centrafricaine. (Ministère des eaux, forêts, chasse et pêche chargé de l'environnement: République Centrafricaine)

Asociación Colombiano De Herbarios 1999. 'Agenda de Investigación en Sistemática/Biodiversidad Siglo XXI.' (Asociación Colombiano de Herbarios: Colombia)

Australian Government Department of the Environment, Water, Heritage and the Arts (2006) 'Survey of Australian Taxonomic Capacity.' (Australian Government Department of the Environment, Water, Heritage and the Arts: Canberra, ACT, Australia)

Bacher S (2012) Still not enough taxonomists: reply to Joppa et al. Trends in Ecology \& Evolution 27(2), 65-66. doi:10.1016/j.tree.2011.11.003

Blackmore S (1996) ‘A Summary of UK Based Expertise in Systematic Biology.’ (UK Systematics Forum)

Bouchet P, Duarte CM (2006) The magnitude of marine biodiversity. In 'The Exploration of Marine Biodiversity Scientific and Technological Challenges'. pp. 33-64. (Fundación BBVA)

Boxshall G, Self D (2011) 'UK Taxonomy \& Systematic Reviews - 2010.' (Natural Environment Research Council: London, UK)

Burnett J, Copp C, Harding PT (1995) Biological recording in the United Kingdom. Present practice and future development. Summary report. Department of the Environment, London, UK. 
Calabuig I, Dieguez C, Izquierdo I, Ramos M, Scharff N, Enghoff H 2003. ENHSIN users: scientific and wider. In 'ENHSIN : the European Natural History Specimen Information Network'. pp. 41-75. (Natural History Museum: London, UK)

Costello MJ, Bouchet P, Emblow CS, Legakis A (2006) European marine biodiversity inventory and taxonomic resources: state of the art and gaps in knowledge. Marine Ecology Progress Series 316, 257-268. doi:10.3354/meps316257

Cribb TH (2004) Living on the edge: parasite taxonomy in Australia. International Journal for Parasitology 34(2), 117123. doi:10.1016/j.ijpara.2003.11.004

Delanay and Associates (2002) 'Capacity Gap Analysis and Statement of Requirement.' (Federal Biosystematics Partnership: Ottawa, ON, Canada)

Eggleton P (1999) Termite species description rates and the state of termite taxonomy. Insectes Sociaux 46, 1-5. doi: $10.1007 / \mathrm{s} 000400050105$

Fontaine B, van Achterberg K, Alonso-Zarazaga MA, Araujo R, Asche M, Aspöck H, Aspöck U, Audisio P, Aukema B, Bailly N, Balsamo M, Bank RA, Belfiore C, Bogdanowicz W, Boxshall G, Burckhardt D, Chylarecki P, Deharveng L, Dubois A, Enghoff H, Fochetti R, Fontaine C, Gargominy O, Lopez MSG, Goujet D, Harvey MS, Heller K-G, van Helsdingen P, Hoch H, De Jong Y, Karsholt O, Los W, Magowski W, Massard JA, McInnes SJ, Mendes LF, Mey E, Michelsen V, Minelli A, Nafria JMN, van Nieukerken EJ, Pape T, De Prins W, Ramos M, Ricci C, Roselaar C, Rota E, Segers H, Timm T, van Tol J, Bouchet P (2012) New species in the Old World: Europe as a frontier in biodiversity exploration, a test bed for 21st century taxonomy. PLoS One 7(5), e36881. doi:10.1371/journal.pone.0036881

Gast F, Krieger Rincón K (2003) 'Actualización Estado de la Investigación en Biodiversidad y de la Cooperación Científica y Técnica en Colombia.' (Instituto de Investigación de Recursos Biológicos Alexander von Humboldt: Bogotá, Colombia)

Gerard F, Hamer M, Raath M (2011) Audit report of South Africa's natural science collections. Collecting now to preserve the future. Totem Media, Johannesburg, South Africa; and South African National Biodiversity Institute, Pretoria, South Africa.

Gleich M, Maxeiner D, Miersch M, Nicolay F, Rendall S (2002) 'Life Counts: Cataloguing Life on Earth.' (Atlantic Monthly Press: New York, NY, USA)

Götzl M, Abdel-Qader O, Ehrendorfer F, Geisler A (2003) 'The Austrian collections and databases on species diversity: an interdisciplinary study for the Global Biodiversity Information Facility.' (Federal Ministry of Education, Science and Culture: Vienna, Austria)

Green SV (1998) The taxonomic impediment in orthopteran research and conservation. Journal of Insect Conservation 2(3-4), 151-159. doi:10.1023/A:1009633811789

Haas F, Haeuser C (2005) Taxonomists: an endangered species? In 'Abstracts of Poster Presentations at the 11th Meeting of the Subsidiary Body on Scientific, Technical and Technological Advice of the Convention on Biological Diversity'. pp. 87-89. (Secretariat of the Convention on Biological Diversity: Montréal, QC, Canada)

Haas F, Haeuser C (2007) How many taxonomists are there? Nationale Kontaktstelle Deutschland. Available at http://www.gti-kontaktstelle.de/taxonomy_E.html [Verified 12 October 2017] 
Hall K (Ed.) (2008) 'Proceedings of the National Taxonomy Forum', 3-4 October 2007, Sydney, NSW, Australia. (Federation of Australian Scientific and Technological Societies (FASTS) and Australian Biological Resources Study (ABRS): Sydney, NSW, Australia)

Hamer M (2012) An assessment of zoological research collections in South Africa. South African Journal of Science 108(11/12), 1090. doi:10.4102/sajs.v108i11/12.1090

Hawksworth DL (1995) The resource base for biodiversity assessments. In 'Global Biodiversity Assessment'. pp. 549605. (Cambridge University Press: New York, NY, USA)

Herbert DG (2001) Museum natural science and the NRF: crisis times for practitioners of fundamental biodiversity science. South African Journal of Science 97(5/6), 168-172.

Herbert DG, Smith GF, Hamer M, Scholtz CH (2001) Taxonomy and systematics research in South Africa: vital research facing a crisis in capacity and resources. Report to the National Research Foundation and the Department of Arts, Culture, Science and Technology.

Herrera A (2002) 'Desarrollo de la Capacidad Taxonómica en América Central : iniciativa mundial en taxonomiaconvenio sobre la diversidad biologica.' (CBD/SIDA/INBiol)

Hopkins GW, Freckleton RP (2002) Declines in the numbers of amateur and professional taxonomists: implications for conservation. Animal Conservation 5(3), 245-249. doi:10.1017/S1367943002002299

House of Lords, Science and Technology Committee (2008) Systematics and Taxonomy: Follow-up. 5th report. House of Lords Science and Technology Committee, London, UK.

Joppa LN, Roberts DL, Pimm SL (2011) The population ecology and social behaviour of taxonomists. Trends in Ecology \& Evolution 26(11), 551-553. doi:10.1016/j.tree.2011.07.010

Klopper RR, Smith GF, Chikuni AC (2002) The global taxonomy initiative in Africa. Taxon 51(1), 159-165. $\underline{\text { doi: } 10.2307 / 1554974}$

Legakis A, Emblow CS (2003) The register of collections of European marine species: an overview. In 'The New Panorama of Animal Evolution'. pp. 603-609. (Pensoft: Sofia, Bulgaria)

Lewinsohn TM (2003) 'Evaluation of the State of Knowledge on Biological Diversity in Brazil: Executive Summary.' (Ministry of the Environment: Brasília, Brazil)

Löbl I, Leschen RAB (2005) Demography of coleopterists and their thoughts on DNA barcoding and the phylocode, with commentary. Coleopterists Bulletin 59(3), 284-292. doi:10.1649/850.1

Lohrmann V, Vohland K, Ohl M, Haeuser C (2012) 'Taxonomische Forschung in Deutschland - eine Übersichtsstudie.' (Christoph Häuser Netzwerk-Forum zur Biodiversitätsforschung Deutschland (NeFo): Berlin, Germany)

Marques AC, Lamas CJE (2006) Sistemática zoológica no Brasil: estado da arte, expectativas e sugestões de ações futuras. Papéis Avulsos de Zoologia 46(3), 139-174.

McCallum ML, McCallum J (2006) Publication trends of natural history and field studies in herpetology. Herpetological Conservation and Biology 1, 62-67. 
Michán L, Llorente JJ (2002) Hacia una historia de la Entomología en México. In 'Biodiversidad, Taxonomía y Biogeografía de Artrópodos en México'. (Eds J Llorente, JJ Morrone) pp. 3-52. (UNAM: Mexico)

Michán L, Llorente Bousquets JE (2003) La taxonomía en méxico durante el siglo XX. Publicaciones Especiales del Museo de Zoología 12, 1-229.

Michán L, Llorente Bousquets J (2010) Bibliometría de la sistemática biológica sobre América Latina durante el siglo XX en tres bases de datos mundiales. Revista de Biología Tropical 58(2), 531-545.

Michán L, Russell JM, Sanchez Pereyra A, Llorens Cruset A, López Beltrán C (2008) Análisis de la sistemática actual en Latinoamérica. Interciencia 33(10), 754-761.

Michán Aguirre L, Morrone JJ (2002) Historia de la taxonomía de Coleoptera en México: Una primera aproximación. Folia Entomologica Mexicana 41(1), 67-103.

Michán Aguirre L, Llorente Bousquets J, Martínez AL, Castro DJ 2004. Breve historia de la Taxonomía de Lepidoptera en México durante el siglo XX. In 'Biodiversidad, Taxonomía y Biogeografía de Artrópodos en México'. pp. 5-42. (Facultad de Ciencias) Available at http://repositorio.fciencias.unam.mx:8080/xmlui/handle/11154/140047 [Verified 3 November 2013]

Nangulah S, Zeidler J (2004) 'National Biodiversity Professional Training Framework. Consultancy report for the Ministry of Environment and Tourism Philippines.' (Association of Systematic Biologists of the Philippines)

National Science and Technology Council, Committee on Science, Interagency Working Group on Scientific Collections (2009) Scientific Collections: Mission-Critical Infrastructure of Federal Science Agencies. (Office of Science and Technology Policy: Washington, DC, USA)

Ng FSP (2008) 'Natural History Museum Malaysia Planning and Development.' (United Nations Development Programme/Forest Research Institute: Malaysia)

O’Dogherty L, De Wever P, Gorican S (2009) Historical perspective: 140 years of Mesozoic radiolarian taxonomy. Geodiversitas 31(2), 357-369. doi:10.5252/g2009n2a5

Office of the Inspector General (2009) 'Museum Collections: Accountability and Preservation.' (US Department of the Interior: Washington, DC, USA)

Oteng-Yeboah A, Kwapong P, Cobblah MA, Smith R, Lyal CHC (2007) 'Taxonomic Needs Assessment for Ghana.' (CSIR/BioNET/NHM: Legon, Accra, Ghana)

Packer L, Grixti JC, Roughley RE, Hanner R (2009) The status of taxonomy in Canada and the impact of DNA barcoding. Canadian Journal of Zoology 87(12), 1097-1110. doi:10.1139/Z09-100

Pallini A, Matiello Fadini MA (2007) Demandas e perspectivas para a Acarologia no Brasil. Neotropical Biological Conservation 2(3), 169-175.

Parnell J (1993) Plant taxonomic research, with special reference to the tropics: problems and potential solutions. Conservation Biology 7(4), 809-814. doi:10.1046/j.1523-1739.1993.740809.x

Petřík P (2007) ‘Global Assessment of Taxonomic Needs and Capacities.' (CBD National Reports: Průhonice, Czech Republic) 
Robles G, Correa M, Ocampo R (Eds) (1996) 'Situación de los herbarios de Centroamérica y el Caribe.' (Centro Agronómico Tropical de Investigación y Enseñanza, Tecnica: Turrialba, Costa Rica)

Rodrigues ASL, Gray CL, Crowter BJ, Ewers RM, Stuart SN, Whitten T, Manica A (2010) A Global Assessment of Amphibian Taxonomic Effort and Expertise. Bioscience 60(10), 798-806. doi:10.1525/bio.2010.60.10.6

Sattout EJ (2004) Lebanon 2005 taxonomy report. National capacities \& needs. American University of Beirut, Beirut, Lebanon.

SBSTTA (1999) The Global Taxonomy Initiative: recommendations from DIVERSITAS Element 3, including an assessment of present knowledge of key species groups. In 'DIVERSITAS/Systematics Agenda 2000 meeting', 1999. p. 34. (Technical Subsidiary Body on Scientific and Technologica Advice: ICSU, Paris, France) Available at https://www.cbd.int/doc/meetings/sbstta/sbstta-04/information/sbstta-04-inf-06-en.pdf [Verified 12 October 2017]

Schminke HK (1994) Wiederaufbau von Forschung und Lehre in Zoosystematik - eine nationale Aufgabe. Spektrum der Wissenschaft 9, 114-116.

Schminke HK (1996) Naturkundliche Sammlungen - das vernachlässigte Erbe? Spektrum der Wissenschaft 1996, 116119.

Shashikyan S, Simonyan G (2002) Assessment of priority capacity building needs for biodiversity. National report. CDB National Reports, Ministry of Nature Protection, Yerevan, Armenia.

Shimura J (2003) 'Global Taxonomy Initiative in Asia. Research Report from the National Institute for Environmental Studies.' (National Institute for Environmental Studies: Tsukuba, Ibaraki, Japan)

Shostak AW (1997) Results of surveys of taxonomic expertise in parasitology in Canada and of interest in national faunal projects on parasites in Canada. Taxonomic Survey and Gap Analysis. Available at http://www.biology.ualberta.ca/parasites/ParSec/texten/modgap.html [Verified 12 October 2017]

Sigogneau A, Barriel V (1998) Positions de la France en Systématique caractérisées par quelques indicateurs bibliométriques. Biosystema 16, 27-36.

Simonetti JA (1997) Biodiversity and a taxonomy of Chilean taxonomists. Biodiversity and Conservation 6(4), $633-637$. doi:10.1023/A:1018345631406

Simonetti JA, Arroyo TK, Spotorno AE, Lozada E (1995) 'Diversidad biologica de Chile.' (Comision Nacional de Investigacion Cientifica y Tecnologica)

Smith GF, Buys M, Walters M, Herbert DG, Hamer M (2008) Taxonomic research in South Africa: the state of the discipline. South African Journal of Science 140(7-8), 254-256.

Tancoigne E, Bole C, Sigogneau A, Dubois A (2011) Insights from Zootaxa on potential trends in zoological taxonomy. Frontiers in Zoology 8, 5. doi:10.1186/1742-9994-8-5

Taylor A (2006) 'United Kingdom Taxonomic Needs Assessment.' (NHM/defra: London, UK)

Taylor PJ, Hamer M (2001) A report on the South African zoological collections audit - 1998. South African Museums Association Bulletin 25(2), 5-20. 
Tillier S, De Wever P (2000) Systématique : ordonner la diversité du vivant - Rapport sur la science et la technologie $\mathrm{n}^{\circ} 11$. Editions Tec \& Doc. Rapport sur la science et la technologie: Paris, France)

Torres-Contreras H (2001) Antecedentes biológicos de hormigas presentes en Chile publicados en revistas científicas nacionales y extranjeras durante el siglo XX. Revista Chilena de Historia Natural 74, 653-668. doi:10.4067/S0716$\underline{078 \times 2001000300011}$

Visher L (Ed.) (1995) Taxonomy in crisis? A report on a national workshop held in Canberra, 18 October 1995. (Australian Biological Resources Study: Canberra, ACT, Australia)

Wilson KL, Cresswell I, Lyal CHC, Shimura J (Eds) (2002) Building capacity: Bangladesh to Bali and beyond. Preliminary report of first Global Taxonomy Initiative Workshop in Asia', September 2002, Putrajaya, Malaysia. pp. 1-54. Available at https://www.cbd.int/doc/meetings/sbstta/sbstta-09/information/sbstta-09-inf-17-en.pdf [Verified 12 October 2017]

Winston JE, Metzger KL (1998) Trends in taxonomy revealed by the published literature. Bioscience 48, $125-128$. $\underline{\text { doi: } 10.2307 / 1313138}$

Ziegler W, Bode HJ, Mollenhauer D, Peters DS, Schminke HK, Trepl L, Türkay M, Zizka G, Zwölfer H (1997) Biodiversitätsforschung: Ihre Bedeutung für Wissenschaft, Anwendung und Ausbildung. Fakten, Argumente und Perspektiven. Kleine Senckenberg Reihe 26, 1-68. 